\title{
East Asian Summer Monsoon Precipitation Response to Variations in Upstream Westerly Wind
}

\author{
Jun-Hyeok Son ( $\boldsymbol{\nabla}$ j-hson@kiost.ac.kr) \\ Korea Institute of Ocean Science and Technology https://orcid.org/0000-0002-7004-8814 \\ Kyong-Hwan Seo \\ Pusan National University
}

\section{Research Article}

Keywords: East Asian summer monsoon, rainband, precipitation, Interannual variability, Tibetan Plateau

Posted Date: June 3rd, 2021

DOI: https://doi.org/10.21203/rs.3.rs-556085/v1

License: (9) This work is licensed under a Creative Commons Attribution 4.0 International License. Read Full License

Version of Record: A version of this preprint was published at Climate Dynamics on February 3rd, 2022. See the published version at https://doi.org/10.1007/s00382-021-06117-9. 


\section{East Asian summer monsoon precipitation response}

17 Prof. Kyong-Hwan Seo

18 Department of Atmospheric Sciences

19 Pusan National University, Busan, South Korea

20 Email: khseo@pusan.ac.kr

$$
\text { Jun-Hyeok Son }{ }^{1,2} \text {, and Kyong-Hwan } \mathrm{Seo}^{2,3^{*}}
$$

${ }^{1}$ Korea Institute of Ocean Science \& Technology, Busan, South Korea

${ }^{2}$ Research Center for Climate Science, Pusan National University, Busan, South Korea

${ }^{3}$ Department of Atmospheric Sciences, Division of Earth Environmental System, Pusan National University, Busan, South Korea 


\section{Abstract}

22 From spring to summer, the East Asian summer monsoon (EASM) rainband migrates northwestward. During summer, East Asian countries experience extensive precipitation due to the EASM rainband, but the springtime monsoon rainband lies over the Pacific. The seasonal evolution of the EASM rainband is influenced by the mechanical effect of the Tibetan Plateau, and seasonal changes in the westerly wind speeds impinging on the Tibetan Plateau are a key driver of this process. In this study, using interannual variability of the upstream zonal wind speed, the dynamical mechanism for the interannual variations of the EASM precipitation is revealed based on the topographically forced stationary Rossby wave theory. The dynamical mechanism regulating interannual variability in the EASM rainband is essentially the same mechanism that drives the seasonal evolution of the climatological EASM rainband. If the westerly winds impinging on the Tibetan Plateau are stronger (weaker) than average, then the EASM rainband shifts eastward (westward). Large variations in the upstream westerly wind during May induced considerable interannual variation in the zonal location of the rainband (up to a $20-30^{\circ}$ shift). The westerly wind speed exhibited less variations in June and July, resulting in a smaller zonal shift of approximately $10^{\circ}$.

38 Keywords: East Asian summer monsoon, rainband, precipitation, Interannual variability, Tibetan Plateau 


\section{Introduction}

Variations in weather and climate are known as one of the most important factors affecting human activities, including the economy, industry, agriculture, environment, and recreation. In particular, East Asian countries experience significant interannual variability in summer monsoon precipitation; therefore, understanding of underlying physical mechanisms for the East Asian summer monsoon (EASM) has long been challenged.

Interannual variations in EASM precipitation are controlled by numerous continental, oceanic, and atmospheric factors. For example, positive sea surface temperature anomalies in the equatorial eastern Pacific during the previous winter season as characterized by El Niño tend to suppress convection over the Philippine Sea, generating poleward atmospheric Rossby wave teleconnections and enhancing the North Pacific subtropical high, which in turn enhances EASM precipitation (e.g., Nitta 1987; Seo et al. 2015; Wang et al. 2000). Furthermore, a circumglobal teleconnection pattern produced by zonally propagating stationary Rossby waves emanating from the North Atlantic or northern Indian subcontinent can also cause anomalous EASM precipitation (e.g., Ding and Wang 2005; Enomoto et al. 2003; Kim et al. 2017; Li and Ruan 2018; Lu et al. 2002; Seo et al. 2012; Wu et al. 2009; Son et al. 2021). Springtime Eurasian snow cover dipole anomaly, above normal in western Eurasia and below normal in eastern Eurasia, induces temperature and circulation anomalies around East Asia that lead to enhanced EASM precipitation (Yim et al. 2010).

The Tibetan Plateau plays various roles in EASM variability. Anomalous Tibetan Plateau heating intensifies the cyclonic circulation which is once developed through the land-sea thermal contrast (Wu et al. 2007), and intense snow melting over the Tibetan Plateau supplies more moisture to the downstream EASM region and increases precipitation (Zhang et al. 2004; Xiao and Duan 2016). The mechanical effect of the mountains induces a faster northward migration of the midlatitude westerly wind across the Tibetan Plateau and tends to result in a shorter duration of monsoon rainfall (Chiang et al. 2017; 2020; Kong and Chiang 2019). Apart from the abovementioned factors, a variety of surface boundary forcing existing in the Pacific, Atlantic, and Indian Oceans; the Eurasian continent; and the Arctic can also influence the intensity of EASM precipitation (e.g., Guo et al. 2014; Kim et al. 2017; Seo et al. 2012; 2015; Xu et al. 2021). 
Recently, Son et al. (2020) showed that the climatological seasonal evolution of the EASM rainband is controlled by variations in the upstream zonal wind speed impinging on the Tibetan Plateau. This is due to the fact that the geopotential height response in topographically forced Rossby wave theory (Held 1983) is a function of the westerly wind speed, damping time scale, and topographical height. Thus, if the damping time scale and mountain height are set, the geopotential height can be solely determined using the upstream zonal wind speed. The importance of the dynamical effect (i.e., circulation) in determining EASM precipitation was demonstrated using a series of sensitivity experiments with a simplified general circulation model (Son et al. 2019).

Motivated by these previous studies, in this study, rather than using the aforementioned continental, oceanic and atmospheric factors responsible for the variation of EASM precipitation on the interannual time scale, we use the year-to-year variation of the westerly wind forcing upstream of Tibet to examine the precipitation variation. As shown by Son et al. (2020), it is expected that the upstream mechanical forcing with a stronger wind speeds induce a more eastward formation in the area of the major northward moisture flux and rainband.

\section{Datasets and Methods}

Monthly climate data derived from the Global Precipitation Climatology Project version 2.3 (Adler et al. 2003) and European Centre for Medium-Range Weather Forecasts Interim Reanalysis (Dee et al. 2011) over the 1979-2018 period were used in this analysis. The Earth Topography Five Minute Grid dataset interpolated to a $2.5^{\circ}$ horizontal resolution was used for the theoretical calculation of geopotential height.

The topographically forced stationary Rossby wave response $\left(\phi_{n}\right.$, geopotential height) is expressed using a theoretical solution derived from the potential vorticity conservation equation as follows:

$$
\phi_{n}=\frac{f_{0}{ }^{2} h_{n}}{g H\left(K^{2}-K_{S}^{2}-i r K^{2} / k \bar{u}\right)}
$$


where $f_{0}$ is the Coriolis parameter $\left(10^{-4} \mathrm{~s}^{-1}\right) ; h_{n}$ is the topographical height $(\mathrm{km}) ; g$ is acceleration due to gravity $\left(9.8 \mathrm{~m} \mathrm{~s}^{-2}\right) ; H$ is the scale height $(8 \mathrm{~km}) ; K^{2}=k^{2}+l^{2}$ is the total wavenumber, where $k=\frac{2 \pi}{2 \pi a \times \cos \left(\frac{\text { latitude }}{180} \pi\right) \times n}$ is the zonal wavenumber and $l=\frac{2 \pi}{\frac{70}{180} \pi a}$ is the meridional wavenumber; $K_{s}{ }^{2}=\beta / \bar{u}$ is the stationary wavenumber; $i=\sqrt{-1}$ is the unit imaginary number; $a$ is the radius of the Earth $(6371 \mathrm{~km}) ; r$ is the inverse of the spindown time $\left(1 / 5 d a y^{-1}\right)$; and $\bar{u}$ is the zonal wind speed $\left(\mathrm{m} \mathrm{s}^{-1}\right)$ at the higher level measured over the immediate upstream region of the mountain range $\left(200 \mathrm{hPa} ; 60-80^{\circ} \mathrm{E} 27.5-35^{\circ} \mathrm{N}\right)$. The forced topographic wave is determined by calculating $h_{n}$, using a Fourier transform (Held 1983; Son et al. 2020).

\section{Climatological characteristics of the EASM}

Following the change of season from spring to summer, the EASM rainband propagates northward; however, in fact, zonal migration of the precipitation is more prominent than meridional movement (Son et al. 2020). The zonal position of the East Asian monsoon rainband is dynamically linked to the flow uplift effect of the Tibetan Plateau (Son et al. 2019). According to Eq. [1], the downstream phase of the Rossby wave is dependent on the upstream westerly wind speed. The upper panel of Fig. 1 shows the geopotential height response to zonal wind forcing. When the wind speed was $6 \mathrm{~m} / \mathrm{s}$ (purple line in Fig. 1), a positive zonal geopotential height gradient region lies over the western part of East Asia (approximately 110 ${ }^{\circ} \mathrm{E}$; thick line). As the westerly wind strengthens, the positive geopotential height gradient region shifts to the east. The climatological seasonal evolution of the EASM rainband is determined by the zonal migration of this positive geopotential height gradient region (Son et al. 2020). Furthermore, the positive geopotential height gradient of geopotential height is geostrophically balanced with the southerly wind, which is crucial for moisture transport to East Asia.

Zonal winds impinging on the Tibetan Plateau $\left(60-80^{\circ} \mathrm{E} 27.5-35^{\circ} \mathrm{N}\right)$ gradually weaken from winter to summer (February to July; Fig. 2b). Conversely, precipitation averaged over the East Asian domain $\left(115-140^{\circ} \mathrm{E} 20-40^{\circ} \mathrm{N}\right)$ increases over the same period. In May, June, and July, 
the mean $200-\mathrm{hPa}$ upstream westerly wind speed is $26.9,16.9$, and $6.03 \mathrm{~m} / \mathrm{s}$, respectively; the respective East Asian precipitation rate is $5.0,6.8$, and $5.8 \mathrm{~mm} /$ day. The downstream stationary Rossby wave response induced by the air uplift effect of the Tibetan Plateau causes a geopotential height anomaly, and the southerly wind shifts east-westward according to the change in the upstream wind speed. In this situation, southerly winds and precipitation mostly cover the EASM domain in June (Son et al. 2020). The zonal wind speed is much weaker in July and August compared to that observed in June; hence, the downstream southerly wind region is shifted westward compared to its location in June. Note that the upstream zonal wind speed tends to balance with the local meridional gradient of the surface temperature field through the thermal wind relationship (Fig. 3).

\section{Response of the EASM rainband to variations in upstream wind forcing on an interannual time scale}

Numerous studies have reported that interannual variability is prominent in EASM precipitation (Fig. 2e). Furthermore, Fig. 2c shows that westerly winds impinging on the Tibetan Plateau also show strong interannual variability. The standard deviations of the interannual zonal wind velocity in May, June, and July were $5.9,4.3$, and $3.8 \mathrm{~m} / \mathrm{s}$, respectively. Figure 1 shows that a large change in zonal wind speed can induce significant zonal movement of the major monsoon rainband; therefore, interannual variation in the peak monsoon precipitation region during July is expected to be smaller than that in May.

Composite differences of the East Asian precipitation between those using above 0.5 and below -0.5 standard deviations of the normalized upstream zonal wind index in May, June, and July are shown in Fig. 4. Green (brown) shading represents a positive (negative) precipitation anomaly for the case when the impinging westerly wind speed is stronger than normal years. From May to June, the climatological evolution of the EASM rainband (black contour in Fig. 4) is characterized by westward propagation; however, the rainband shifts eastward compared to the climatological region due to positive forcing induced by zonal wind anomaly. The eastward shift of the precipitation region in the monthly dataset is caused by the slower northwestward migration of the monsoon rainband. This means that the onset and withdrawal 
dates of the EASM are partly controlled by the westerly wind speed impinging on the Tibetan Plateau. One more interesting point of this result is that the extent of zonal shift in the rainband is greatest (lowest) in May (July), corresponding with the month-to-month interannual variability of the upstream zonal wind velocity.

Figure 5 shows the climatological 850-hPa geopotential height (contour) and the composite difference field of the geopotential height averaged over 850-300 hPa (shading) for normalized zonal wind index standard deviations above 0.5 and below $-0.5 \mathrm{~m} / \mathrm{s}$ in May, June, and July. The mass-weighted vertical average of the geopotential height illustrates the barotropic Rossby wave response affected by upstream zonal wind forcing. The pattern of the composite geopotential height anomaly averaged over 850-300 hPa was similar to that at $850 \mathrm{hPa}$ (not shown). Since the zonal geopotential height gradient represents the strength of the meridional wind, this region is of interest. In May, this positive gradient anomaly appears over the region from $150^{\circ} \mathrm{E} 20^{\circ} \mathrm{N}$ to $165^{\circ} \mathrm{E} 30^{\circ} \mathrm{N}$ (Fig. 5), which is consistent with the positive precipitation anomaly region (Fig. 4). The positive geopotential height gradient region extends from $130{ }^{\circ} \mathrm{E}$ $20^{\circ} \mathrm{N}$ to the northeast in June and from $130^{\circ} \mathrm{E} 25^{\circ} \mathrm{N}$ to $140^{\circ} \mathrm{E} 30^{\circ} \mathrm{N}$ in July (Fig. 5). In both June and July, these gradient regions overlapped the anomalous precipitation domain. In July, more rain occurs over the monsoon rainband (Fig. 4c); however, the western part of the rainband (extending from China to Korea) shows a very slight eastward shift, whereas the eastern part shows a considerable eastward shift. Enhanced precipitation over the western part of the rainband is due to the intensified geopotential height meridional gradient (Fig. 5c), which leads to a stronger confrontation between two air masses with different thermodynamic properties over this region (Seo et al. 2015).

\section{Conclusion and discussion}

In this study, we showed that the zonal location of the EASM rainband is impacted by changes in the speed of the westerly wind impinging on the Tibetan Plateau at an interannual timescale. The EASM rainband is formed between low and high geopotential heights, and this stationary atmospheric wave pattern is shifted eastwards as the upstream wind speed strengthens (Fig. 6). In July, the Rossby wave phase shift was smaller than that observed in May or June due to a smaller variation in the upstream westerly wind speed. 
The horizontal shape of the monsoon rainband in May and June can be depicted as a straight line from the southwest to the northeast; however, in July the rainband shows a peculiar stepped structure, as shown in Fig. 4. The July rainfall pattern may be related to the zonally disparate distribution of air masses. The frontal system over the western portion of the EASM rainband is formed by the warm continental and tropical monsoon air masses; however, the eastern front is developed by the confrontation of the warm North Pacific and cold Okhotsk air masses (Seo et al. 2015; Tomita et al. 2011).

Topographically forced stationary Rossby wave theory is the essential mechanism for the generation and evolution of the EASM rainband. In particular, this dynamical mechanism may be one of the most fundamental processes and this explains not only climatological characteristics of the EASM but also its interannual variability. Therefore, if we observe the upstream westerly wind speed impinging on the Tibetan Plateau, the location and precipitation anomaly of the EASM rainband can be estimated. As shown in Fig. 2, interannual variability is dominant in both impinging zonal wind speed and EASM precipitation; however, global warming may also change the meridional distribution of the surface temperature, westerly wind speeds, and EASM precipitation in the future. Therefore, a more explicit understanding of the Rossby wave and the role of upstream westerly wind speeds is needed to estimate future changes in the EASM.

\section{Acknowledgments}

This research was part of the project titled "Improvements of ocean prediction accuracy using numerical modeling and artificial intelligence technology," funded by the Ministry of Oceans and Fisheries, Korea and it was supported by the National Research Foundation of Korea (NRF) grant funded by the Korea government (MSIP) (No. NRF-2020R1A2C2009414). We are grateful to the reviewers for their valuable comments and suggestions, which improved the paper. 
References

Adler RF, Huffman GJ, Chang A, et al (2003) The version 2 Global Precipitation Climatology Project (GPCP) monthly precipitation analysis (1979-present). $J$ Hydrometeorol 4:1147-1167

Chiang JCH, Kong W, Battisti D (2020) Origins of East Asian summer monsoon seasonality. Journal of Climate 33:7945-7965. https://doi.org/10.1175/JCLI-D-19-0888.1

Chiang JCH, Swenson L, Kong W (2017) Role of seasonal transitions and the westerlies in the interannual variability of the East Asian summer monsoon precipitation. Geophysical Research Letters 44:3788-3795. https://doi.org/10.1002/2017GL072739

Ding QH, Wang B (2005) Circumglobal teleconnection in the Northern Hemisphere summer. $J$ Climate 18:3483-3505

Enomoto T, Hoskins BJ, Matsuda Y (2003) The formation mechanism of the Bonin high in August. Quart J Roy Meteor Soc 129:157-178

Guo D, Gao Y, Bethke I, Gong D, Johannessen OM, and Wang H (2014) Mechanism on how the spring Arctic sea ice impacts the East Asian summer monsoon. Theor Appl Climatol 115:107-119. https://doi.org/10.1007/S00704-013-0872-6

Held IM (1983) Stationary and quasi-stationary eddies in the extratropical troposphere. Theory, Large-Scale Dynamical Processes in the Atmosphere BJ Hoskins and RP Pearce Eds Academic Press 127-168

Kim JY, Seo KH, Son JH, Ha KJ (2017) Development of statistical prediction models for Changma precipitation: An ensemble approach. Asia-Pacific Journal of Atmospheric Sciences 53:207-216. doi:10.1007/s13143-017-0027-2

Kong W, Chiang JCH (2019) Interaction of the westerlies with the Tibetan Plateau in determining the mei-yu termination. Journal of Climate 33:339-363

Li JP, Ruan CQ (2018) The North Atlantic-Eurasian teleconnection in summer and its effects on Eurasian climates. Environ Res Lett 13:024007. https://doi.org/10.1088/1748- 
Lu RY, Oh JH, Kim BJ (2002) A teleconnection pattern in upper-level meridional wind over the North African and Eurasian continent in summer. Tellus 54A:44-55

Nitta T (1987) Convective activities in the tropical western Pacific and their impact on the Northern Hemisphere summer circulation. J Meteor Soc Japan 65:373-390

Seo KH, Son JH, Lee SE, Tomita T, Park HS (2012) Mechanisms of an extraordinary East Asian summer monsoon event in July 2011. Geophys Res Lett 39:L05704. https://doi.org/10.1029/2011GL050378

Seo KH, Ok J, Son JH, Cha DH (2013) Assessing future changes in the East Asian summer monsoon using CMIP5 coupled models. $J$ Climate 26:7662-7675. https://doi.org/10.1175/JCLI-D-12-00694.1

Seo KH, Son JH, Lee JY, Park HS (2015) Northern East Asian monsoon precipitation revealed by air mass variability and its prediction. J Climate 28:6221-6233. https://doi: 10.1175/JCLI-D-14-00526.1

Son JH, Seo KH, Wang B (2019) Dynamical control of the Tibetan Plateau on the East Asian summer monsoon. Geophysical Research Letters 46:7672-7679. https://doi.org/10.1029/2019GL083104

Son JH, Seo KH (2020) Mechanisms for the Climatological Characteristics and Interannual Variations of the Guinea Coast Precipitation: Early Summer West African Monsoon. Atmosphere 11:396. https://doi:10.3390/atmos11040396

Son JH, Seo KH, Wang B (2020) How does the Tibetan Plateau dynamically affect downstream monsoon precipitation? Geophys Res Lett 47. https://doi.org/10.1029/2020GL090543

Son JH, Seo KH, Son SW, Cha DH (2021) How does Indian monsoon regulate the Northern Hemisphere stationary wave pattern? Front Earth Sci 8:599745. https://doi: $10.3389 /$ feart.2020.599745

Wang B, Wu R, Fu X (2000) Pacific-East Asia teleconnection: How does ENSO affect East 
Wang B, Xiang B, Lee JY (2013) Subtropical High predictability establishes a promising way for monsoon and tropical storm predictions. PNAS https://doi: 10.1073/pnas. 1212646110

Wu G, Liu Y, Zhang Q, Duan A, Wang T, et al (2007) The influence of mechanical and thermal forcing by the Tibetan Plateau on Asian climate. J Hydrometeor 8:770-789

Wu Z, Wang B, Li J, Jin FF (2009) An empirical seasonal prediction model of the east Asian summer monsoon using ENSO and NAO.J Geophys Res 114:D18120. https://doi:10.1029/2009JD011733

Xiao, Z, Duan A (2016) Impact of Tibetan Plateau snow cover on the interannual variability of the East Asian summer monsoon. J Climate 29:8495-8514

Xu B, Chen H, Gao C, Zeng G, Huang Q (2021) Abnormal Change in Spring Snowmelt Over Eurasia and Its Linkage to the East Asian Summer Monsoon: The Hydrological Effect of Snow Cover. Front Earth Sci 8:594656. https://doi: 10.3389/feart.2020.594656

Yim SY, Jhun JG, Lu R, Wang B (2010) Two distinct patterns of spring Eurasian snow cover anomaly and their impacts on the East Asian summer monsoon. J Geophys Res 115:D22113. doi:10.1029/2010JD013996

Zhang, YS, Li T, Wang B (2004) Decadal change of the spring snow depth over the Tibetan 280 Plateau: The associated circulation and influence on the East Asian summer monsoon. $J$ 

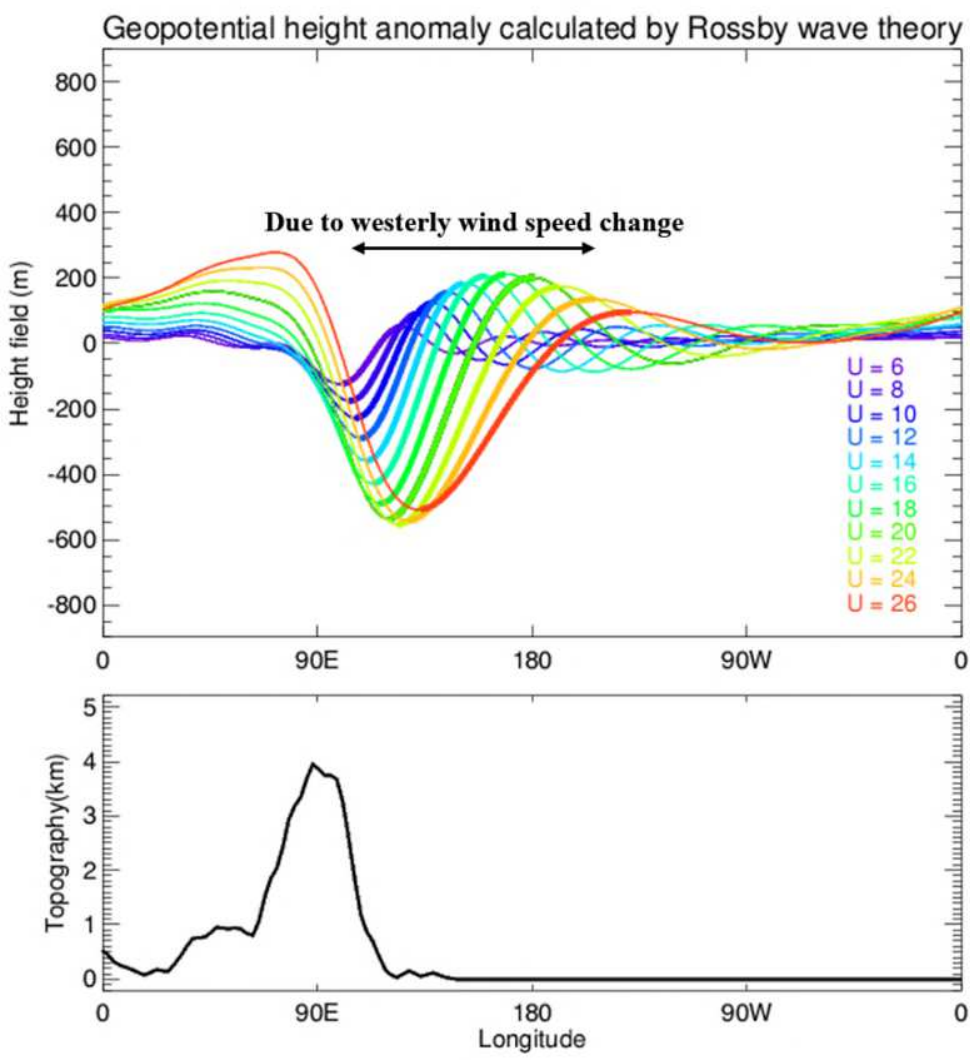

284 Figure 1. Theoretical prediction of the geopotential height calculated using zonal wind speeds 285 from 6-26 m/s (top panel) and Eurasian topography along $30^{\circ} \mathrm{N}$ (bottom panel). The thick line sections in the top panel represent regions with a positive geopotential height gradient. 
(a) Climatological precipitation and zonal wind speed at $200 \mathrm{hPa}$ on MJJ

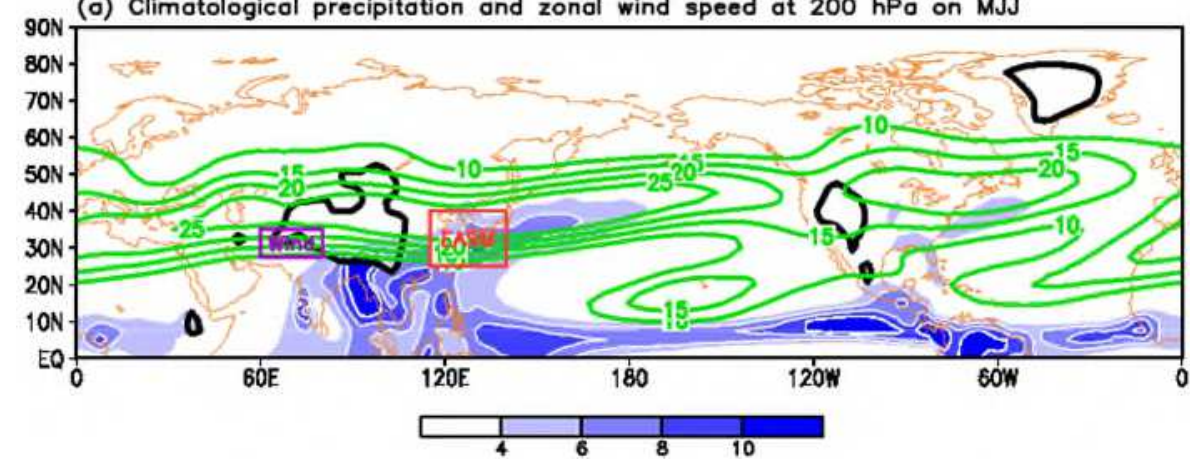

(b) Zonal wind impinging on the Tibet

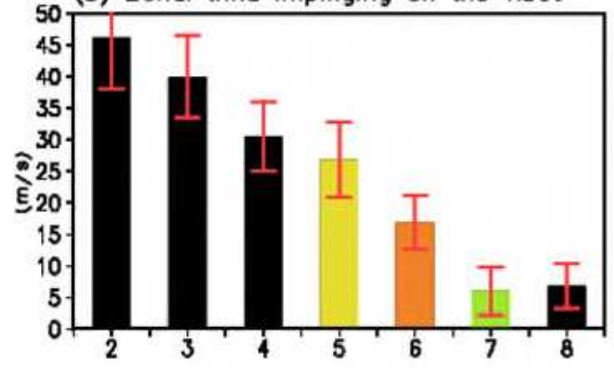

(c) Time series in $\mathrm{Ma}$, June, and July
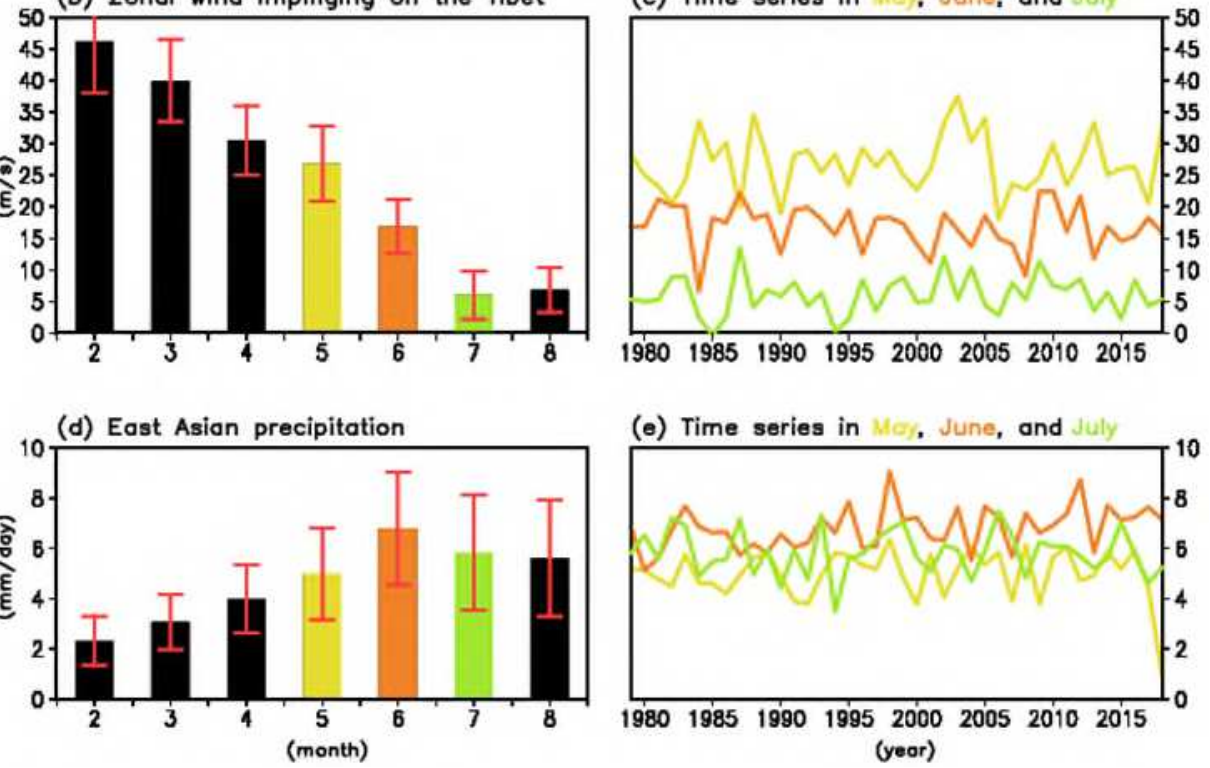

Figure 2. (a) Climatological precipitation (shading) and 200-hPa westerly winds (contour) averaged over May, June, and July (MJJ). The black contour denotes topography exceeding $1500 \mathrm{~m}$ altitude, westerly winds impinging on the Tibetan Plateau are denoted by the purple box $\left[60-80^{\circ} \mathrm{E} 27.5-35^{\circ} \mathrm{N}\right]$, and the domain for East Asian summer monsoon (EASM) precipitation is denoted by the red box $\left[115-140^{\circ} \mathrm{E} 20-40^{\circ} \mathrm{N}\right]$.

(b) Domain averaged climatological monthly mean 200 -hPa westerly wind speeds and interannual variation $( \pm 1.0$ standard deviation; denoted by the red error bars) for winds impinging the Tibetan Plateau. (c) Time series of monthly mean 200-hPa westerly wind speeds in May, June, and July for winds impinging the Tibetan Plateau. (d) and (e) are the same as (b) and (c), respectively, except they show East Asian domain averages of precipitation. 

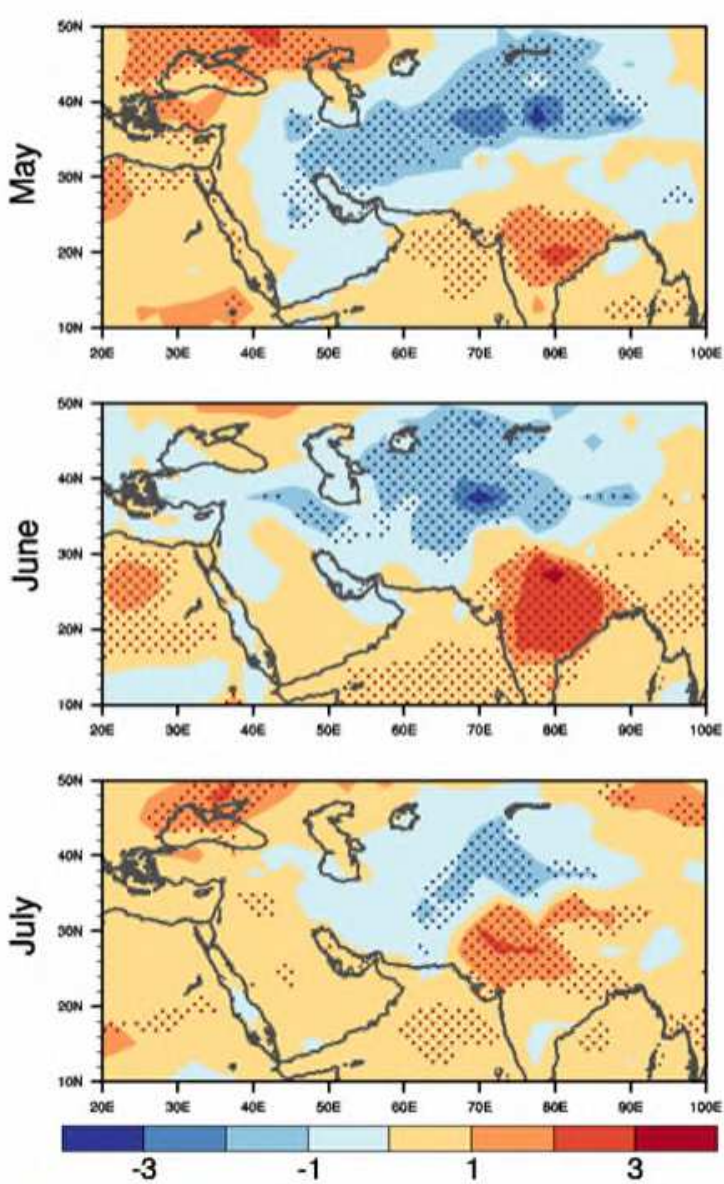

300 Figure 3. Composite surface temperature differences between years with normalized zonal 301 wind index standard deviations above 0.5 and below $-0.5 \mathrm{~m} / \mathrm{s}$ in May, June, and July. Hatching represents regions that are significant at the $95 \%$ confidence level. 

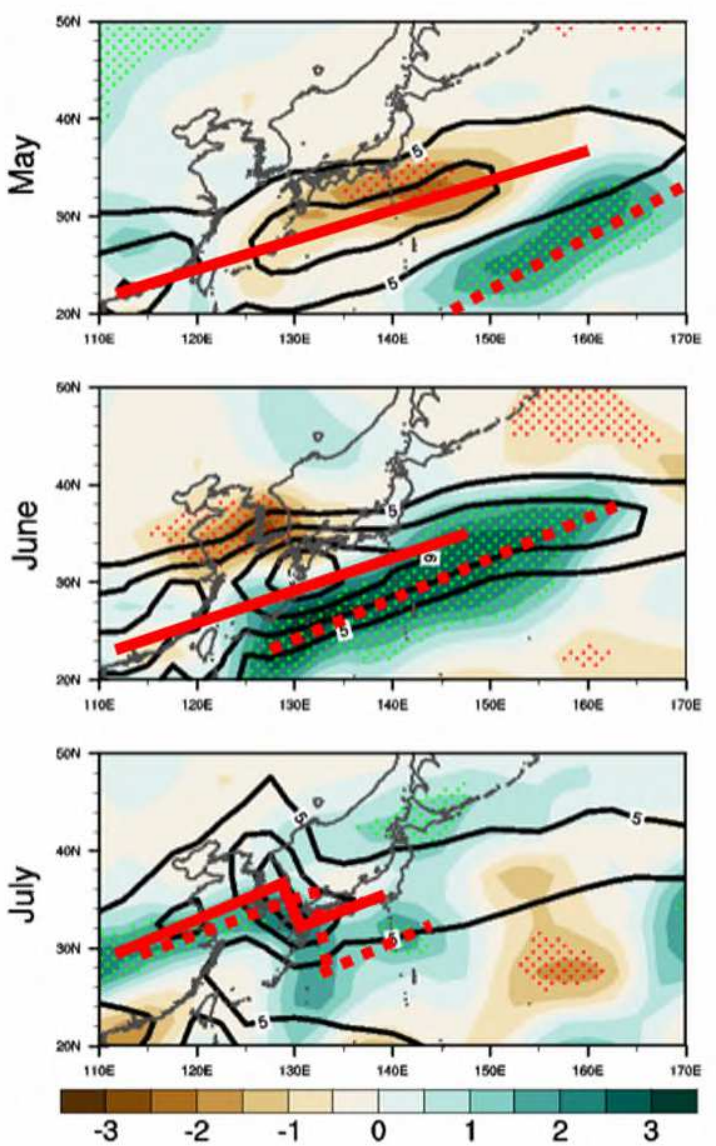

304 Figure 4. Climatological mean precipitation (contour), and the composite difference in precipitation (shading) between years with normalized zonal wind index standard deviations above 0.5 and below $-0.5 \mathrm{~m} / \mathrm{s}$ in May, June, and July. Hatching represents regions that are significant at the $95 \%$ confidence level. The solid red line represents the climatological precipitation peak (i.e., solid black line) and the dotted red line shows the precipitation peak for the composite difference (i.e., shading) in each month. 

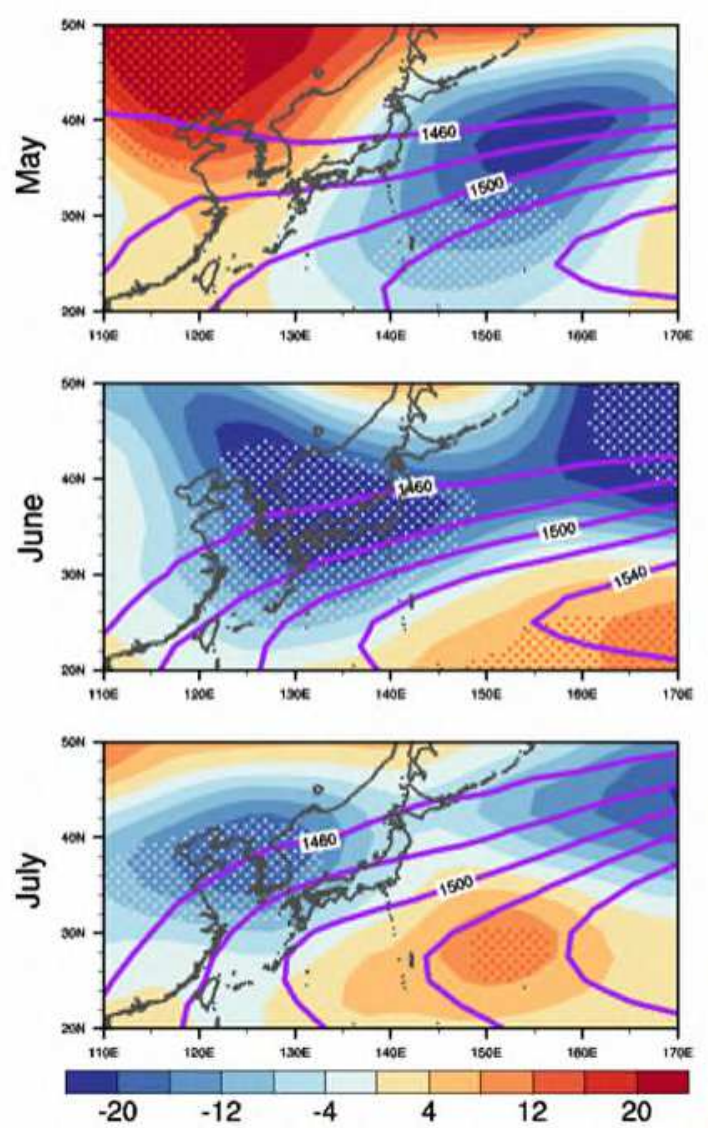

311 Figure 5. Climatological mean $850-\mathrm{hPa}$ geopotential height (contour), and the composite 312 difference in the mean $850-300 \mathrm{hPa}$ geopotential height between years with normalized zonal 313 wind index standard deviations above 0.5 and below $-0.5 \mathrm{~m} / \mathrm{s}$ in May, June, and July. Hatching 314 represents regions that are significant at the $95 \%$ confidence level. 
Flow uplift effect of the westerly wind forcing and downstream Rossby wave response

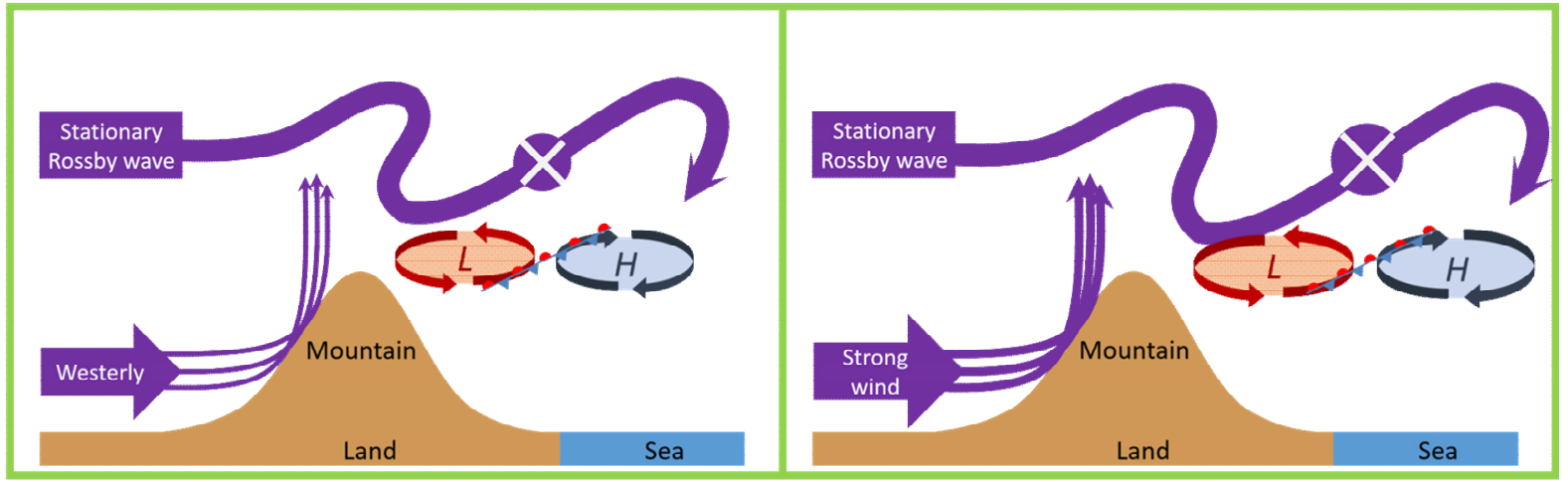

316 Figure 6. Schematic showing the eastward shift in the Rossby wave phase due to increased 317 zonal wind forcing. 


\section{Figures}
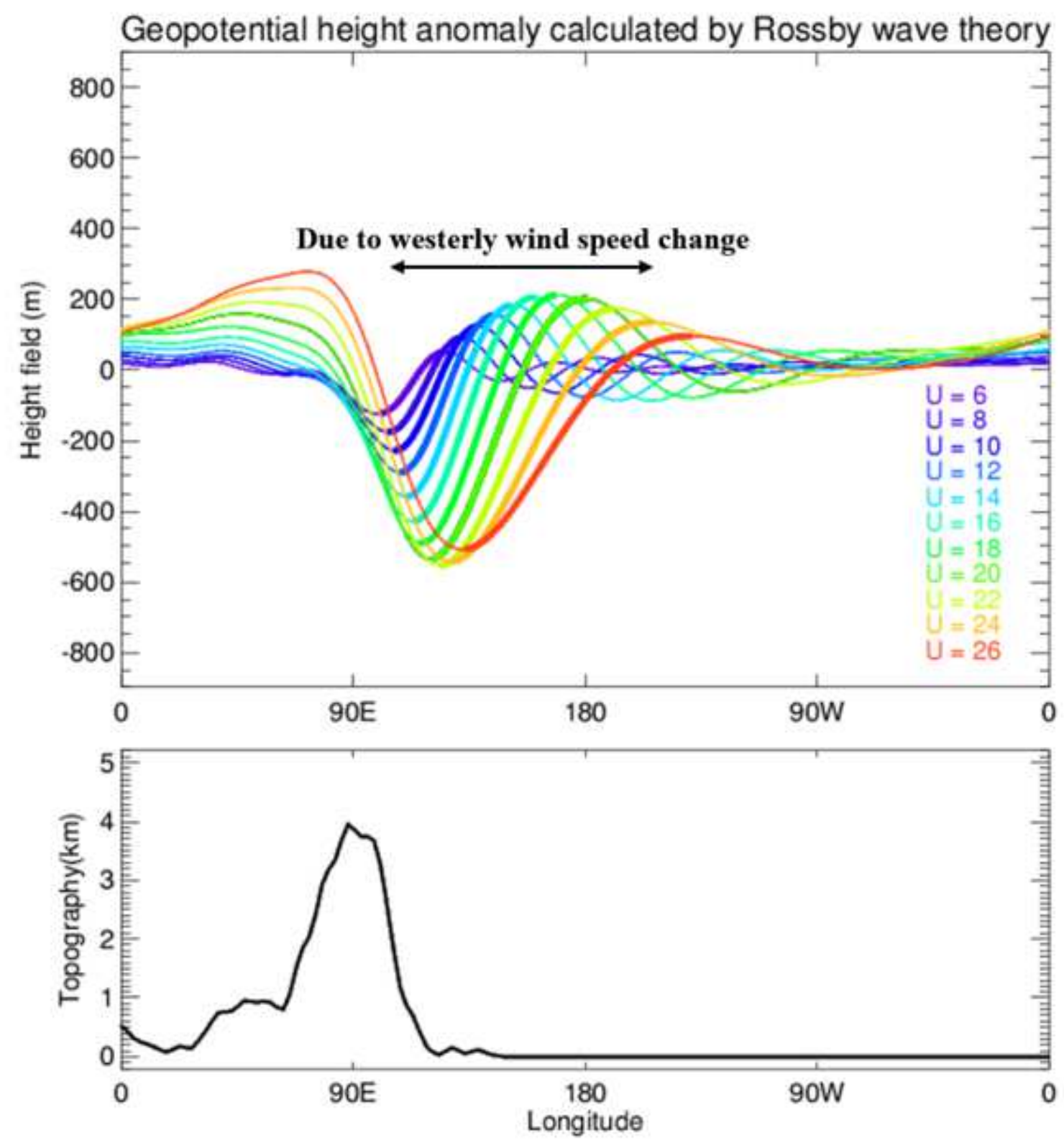

Figure 1

Theoretical prediction of the geopotential height calculated using zonal wind speeds from $6-26 \mathrm{~m} / \mathrm{s}$ (top panel) and Eurasian topography along $30^{\circ} \mathrm{N}$ (bottom panel). The thick line sections in the top panel represent regions with a positive geopotential height gradient. 
(a) Climatological precipitation and zonal wind speed at $200 \mathrm{hPa}$ on MJJ
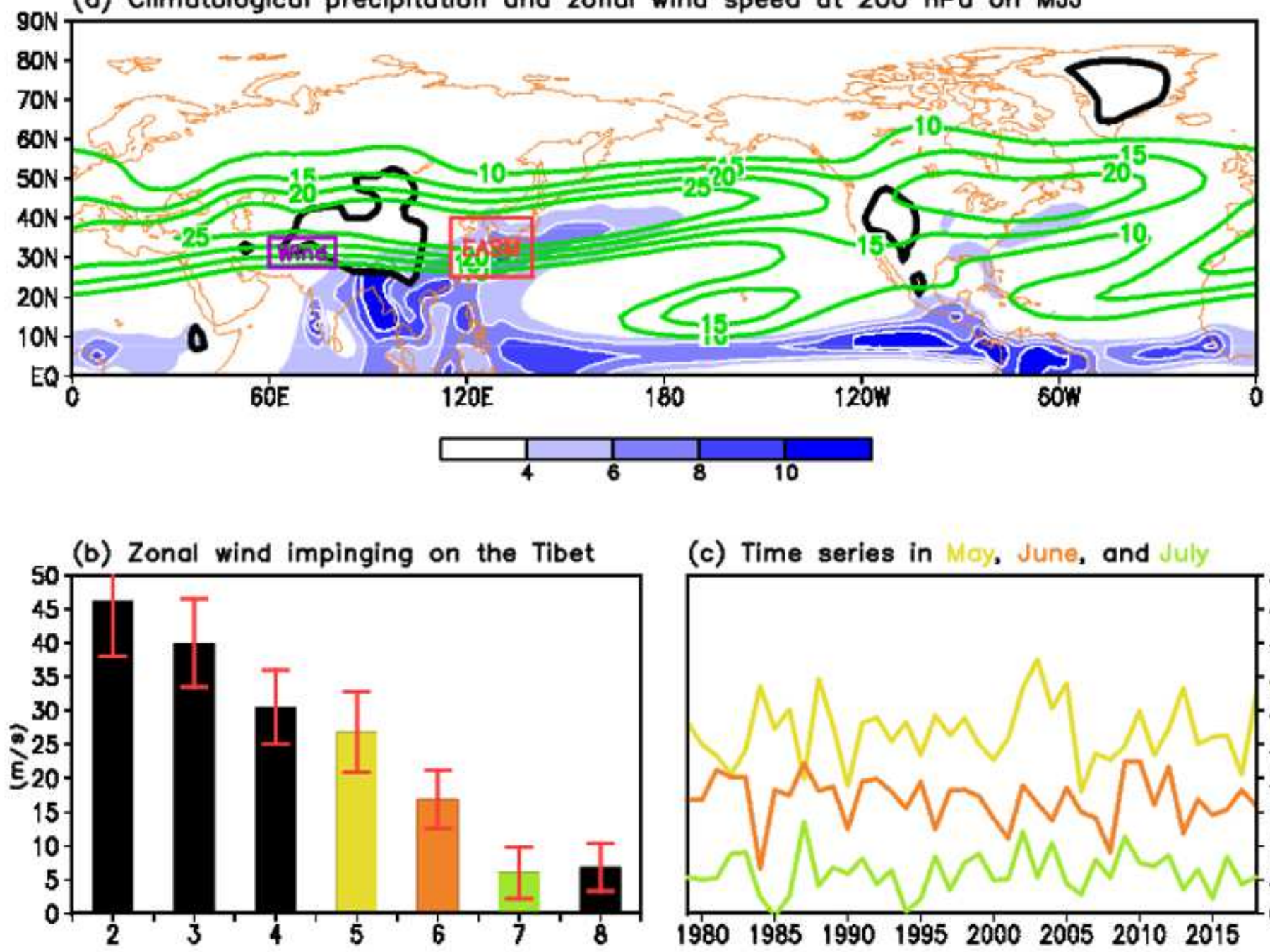

(c) Time series in May, June, and July

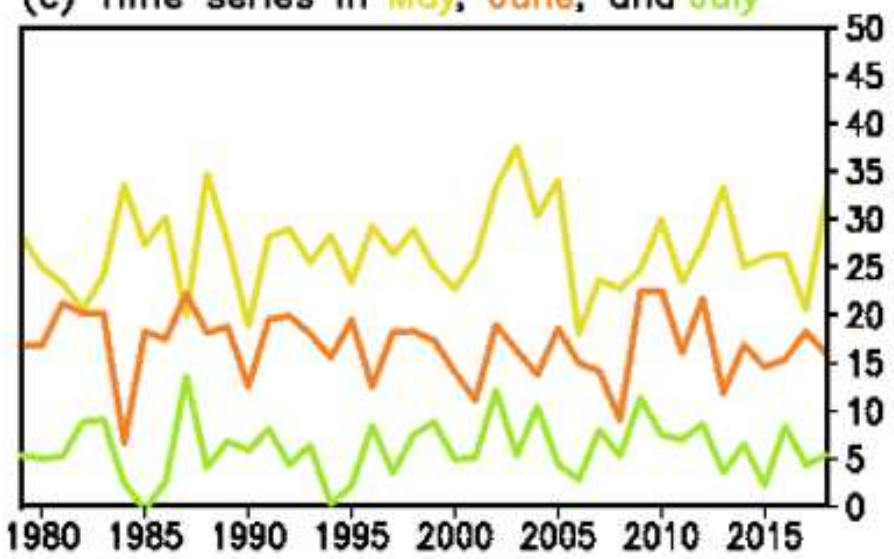

(d) East Asian precipitation

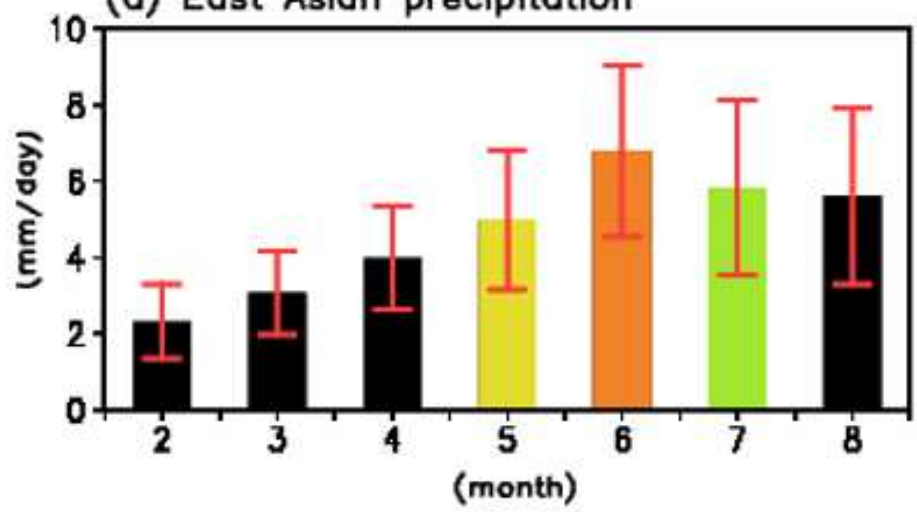

(e) Time series in May, June, and July

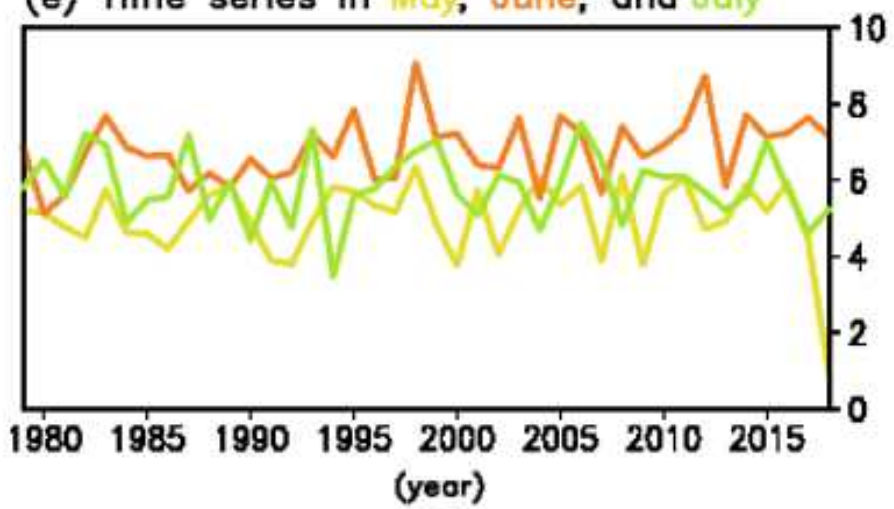

Figure 2

(a) Climatological precipitation (shading) and 200-hPa westerly winds (contour) averaged over May, June, and July (MJJ). The black contour denotes topography exceeding $1500 \mathrm{~m}$ altitude, westerly winds impinging on the Tibetan Plateau are denoted by the purple box [60-80 $\mathrm{E} 27.5-35^{\circ} \mathrm{N}$ ], and the domain for East Asian summer monsoon (EASM) precipitation is denoted by the red box [115-140 $\left.\mathrm{E} 20-40^{\circ} \mathrm{N}\right]$. (b) Domain averaged climatological monthly mean 200-hPa westerly wind speeds and interannual 
variation ( \pm 1.0 standard deviation; denoted by the red error bars) for winds impinging the Tibetan Plateau. (c) Time series of monthly mean 200-hPa westerly wind speeds in May, June, and July for winds impinging the Tibetan Plateau. (d) and (e) are the same as (b) and (c), respectively, except they show East Asian domain averages of precipitation. Note: The designations employed and the presentation of the material on this map do not imply the expression of any opinion whatsoever on the part of Research Square concerning the legal status of any country, territory, city or area or of its authorities, or concerning the delimitation of its frontiers or boundaries. This map has been provided by the authors.
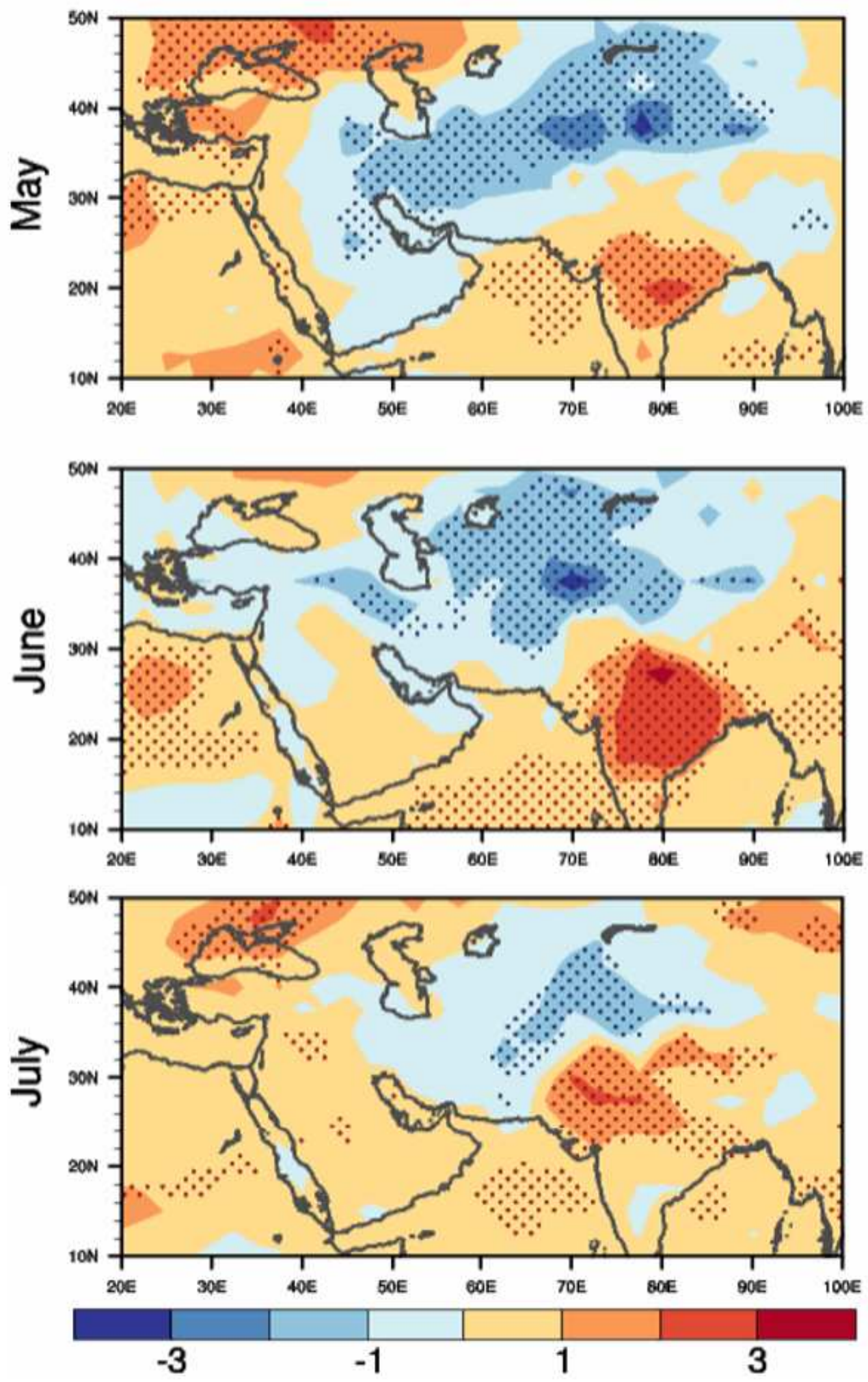


\section{Figure 3}

Composite surface temperature differences between years with normalized zonal wind index standard deviations above 0.5 and below $-0.5 \mathrm{~m} / \mathrm{s}$ in May, June, and July. Hatching represents regions that are significant at the $95 \%$ confidence level. Note: The designations employed and the presentation of the material on this map do not imply the expression of any opinion whatsoever on the part of Research Square concerning the legal status of any country, territory, city or area or of its authorities, or concerning the delimitation of its frontiers or boundaries. This map has been provided by the authors.
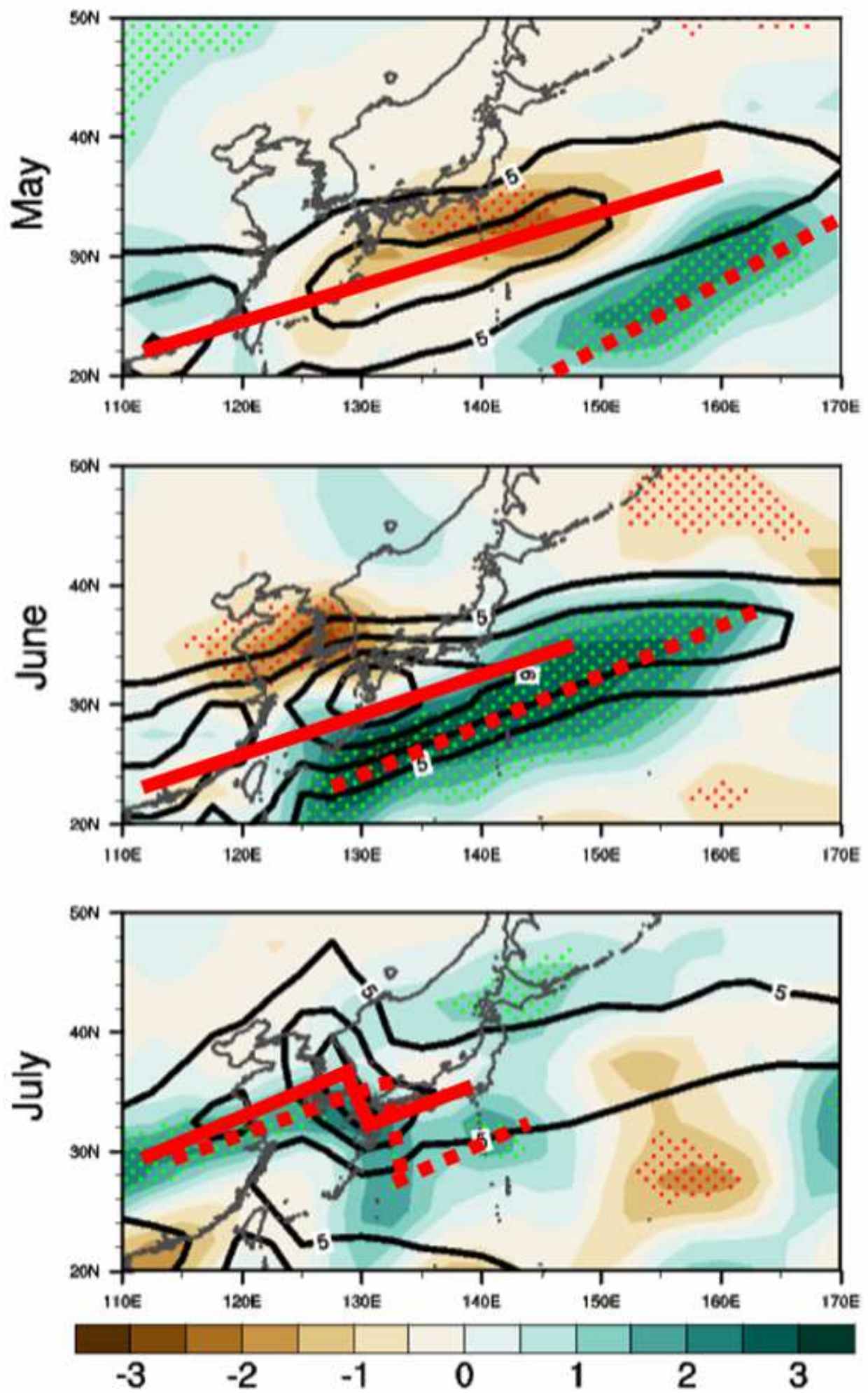


\section{Figure 4}

Climatological mean precipitation (contour), and the composite difference in precipitation (shading) between years with normalized zonal wind index standard deviations above 0.5 and below $-0.5 \mathrm{~m} / \mathrm{s}$ in May, June, and July. Hatching represents regions that are significant at the $95 \%$ confidence level. The solid red line represents the climatological precipitation peak (i.e., solid black line) and the dotted red line shows the precipitation peak for the composite difference (i.e., shading) in each month. Note: The designations employed and the presentation of the material on this map do not imply the expression of any opinion whatsoever on the part of Research Square concerning the legal status of any country, territory, city or area or of its authorities, or concerning the delimitation of its frontiers or boundaries. This map has been provided by the authors. 

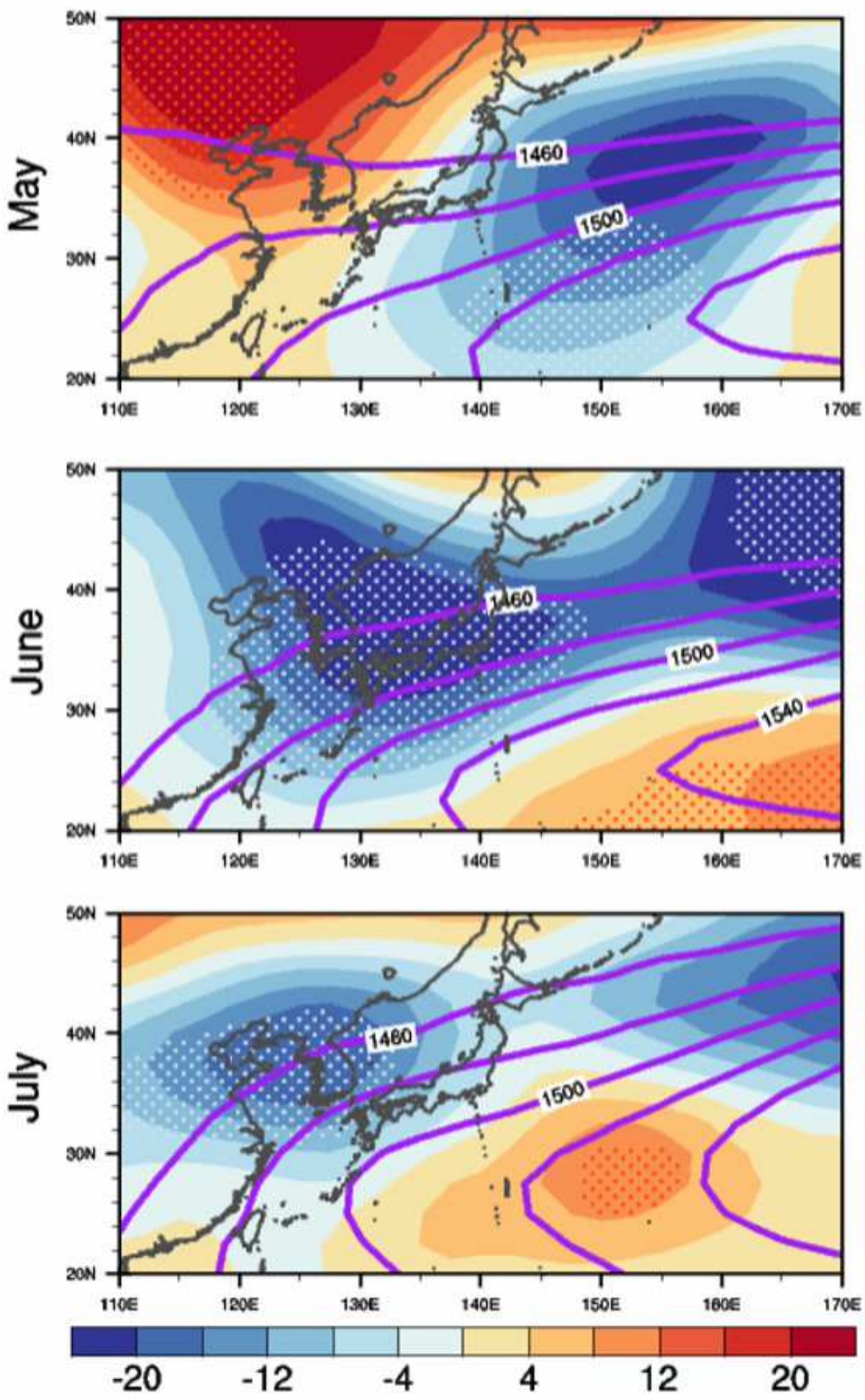

Figure 5

Climatological mean 850-hPa geopotential height (contour), and the composite difference in the mean 850-300 hPa geopotential height between years with normalized zonal wind index standard deviations above 0.5 and below $-0.5 \mathrm{~m} / \mathrm{s}$ in May, June, and July. Hatching represents regions that are significant at the $95 \%$ confidence level. Note: The designations employed and the presentation of the material on this map do not imply the expression of any opinion whatsoever on the part of Research Square concerning 
the legal status of any country, territory, city or area or of its authorities, or concerning the delimitation of its frontiers or boundaries. This map has been provided by the authors.

Flow uplift effect of the westerly wind forcing and downstream Rossby wave response

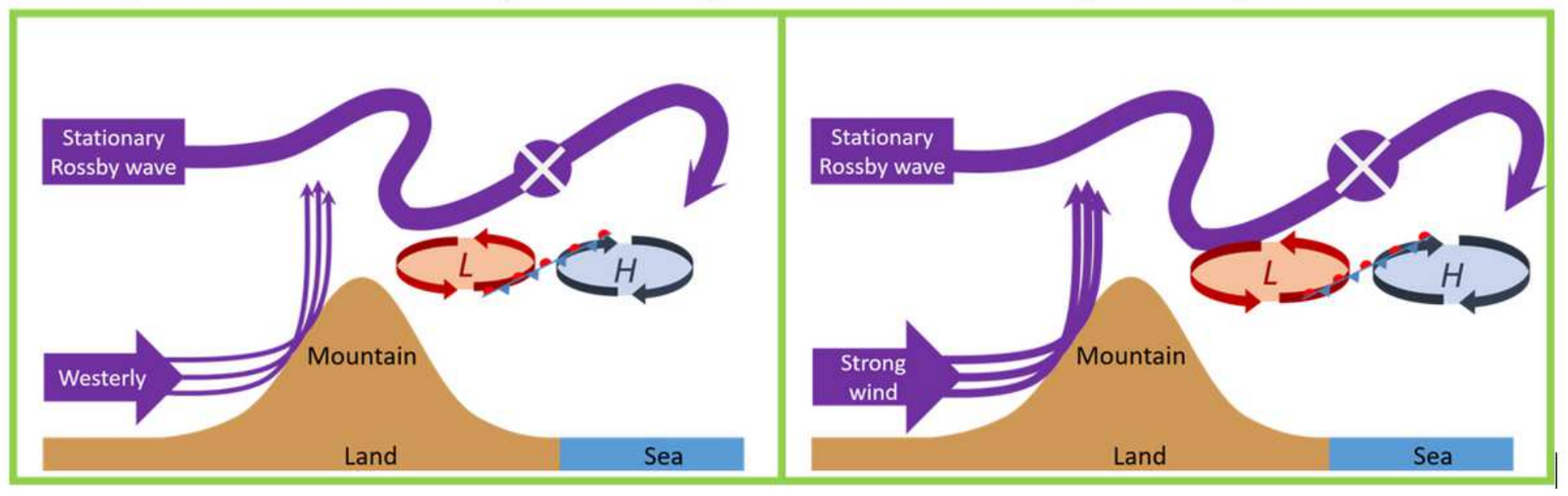

\section{Figure 6}

Schematic showing the eastward shift in the Rossby wave phase due to increased zonal wind forcing. 